\title{
The religious geography of Marvell's “An Horatian Ode”: popery, presbytery, and parti-coloured picts
}

\author{
Stewart Mottram \\ University of Hull \\ S.Mottram@hull.ac.uk
}

\begin{abstract}
Marvell's “Ode” (1650) is an English poem about a British problem - a problem further problematized by religion. The "Ode" lauds Cromwell's Irish and Scottish campaigns, but English responses to these "colonial" wars were in reality complicated by protestant infighting among presbyterians, independents, and sectarians. Writers like Milton and Nedham rallied English support for Cromwell's Irish campaign by recycling Spenserian stereotypes of Irish catholic barbarity. But Milton and Nedham also undercut English protestant unity by flinging these same anti-catholic stereotypes at Scottish presbyterians in Belfast and Edinburgh. Departing from previous studies, this article argues that Marvell's “Ode" eschews Milton and Nedham's antiPresbyterianism in ways calculated to elide, rather than divide, protestant communities. The article explores how the "Ode" presents Cromwell's Irish and Scottish campaigns as exclusively anti-catholic (rather than anti-presbyterian) crusades, comparing Marvell's presentation of Cromwell in the "Ode" with his identification of Cromwell as an anti-catholic crusader in "First Anniversary" (1655). Both poems anticipate in this respect Marvell's later anti-catholic, but prononconformist, approach to Ireland in Rehearsal transpros'd (1672-1673). The article
\end{abstract}


is therefore concerned to root Marvell's post-Restoration commitment to protestant tolerationism within the anti-catholic language of the "Ode".

Keywords: Andrew Marvell; John Milton: Observations; Marchamont Nedham: Mercurius Politicus; Edmund Spenser: A View of the State of Ireland; Cromwell and Ireland; Cromwell and Scotland, anti-catholicism, presbyterianism

Andrew Marvell's “An Horatian Ode upon Cromwell's Return from Ireland” is a centripetal poem, its central lines a meditation on that century's central event, the 'memorable scene' of Charles I's execution on 30 January $1649 .{ }^{1}$ The poem's sympathies for the king's performance on the 'tragic scaffold' erected outside the Banqueting House at Whitehall - 'He nothing common did, or mean', Marvell writes, 'Nor called the Gods with vulgar spite' - contrasts with the implied vulgarity of the soldiers who with 'bloody hands' applaud the unfurling tragedy on stage. ${ }^{2}$ Whether the poem sees royalist tragedy or republican opportunity in the regicide is a question that not only continues to divide critics; it is also one that has historically detracted attention from the significance of the two 'kingdoms' - Ireland and Scotland inhabiting the poem's peripheries. ${ }^{3}$ The poem's mid-point is occupied with Whitehall, yet it is from Ireland that Cromwell returns to Whitehall three quarters of the way through the "Ode", and 'to the Commons' feet presents | A kingdom, for his first year's rents'. ${ }^{4}$ From these Irish victories the poem foretells Cromwell's military success in Scotland, whence Cromwell 'March[es] indefatigably on' at the poem's close. ${ }^{5}$ For one seventeenth-century reader, the archipelagic arc of Cromwell's postregicidal career was as central to the "Ode" as its central meditation on Cromwell's part in Charles I's tragedy. The poem, as printed in the two known un-cancelled 
copies of Miscellaneous Poems (1681), has Cromwell 'cast the Kingdome old | Into another Mold', but the manuscript version in the Bodleian Library speaks of 'kingdoms' in the plural. ${ }^{6}$ It is an emendation that has animated more recent archipelagic interest in the poem's Celtic margins, in keeping with the archipelagic turn of early modern literary criticism more generally in recent decades. ${ }^{7}$

David J. Baker writes that Marvell's “"Ode” is a poem by an Englishman who glimpses the potential for more-than-Englishness that Cromwell's victories seem to imply'. Yet the politics of British-Irish state-formation is not the only framework inflecting Marvell's representations of Ireland and Scotland in the "Ode". Also key is the question of Marvell's religion. This article develops on the archipelagic angle of Baker's and other recent approaches to the "Ode" to offer a more religiously inflected reading of Marvell's representation of these nations in the poem, one attuned to the potential for religious differences to divide as well as elide protestant communities across the British-Irish archipelago. David Coleman reminds us that national identities 'more often than not include a religious component in their self-definition' ${ }^{8}$ This was particularly true of mid-seventeenth century England, where identity was as much bound up with religious as with national allegiances, and thus was as open to permutation as the religious situation itself in commonwealth England, where Independency vied with Presbyterianism over questions of church government, and both faced challenges from the rise in religious sectarianism. As these religious divisions undercut national unity in England, they also complicated English perspectives on its Celtic neighbours, muddying support for Cromwell's Irish campaign in 1649-50 among English Levellers, and support for Cromwell's invasion of Scotland among English presbyterians, including Marvell's future patron Thomas, 
third lord Fairfax, who resigned as general of the parliamentary army in June 1650 in protest of Cromwell's impending invasion. ${ }^{9}$

In two key interventions into debates over Marvell's relative royalist versus republican sympathies, Blair Worden and David Norbrook argue that the poem makes its republicanism manifest through verbal and ideological parallels with republican writing by Milton and Nedham, among others. ${ }^{10}$ Central to these arguments is the claim that Marvell shares Milton and Nedham's readiness to think of 'Cromwell as a Machiavellian prince'. ${ }^{11}$ While I also want to acknowledge Marvell's familiarity with Milton and Nedham's Machiavellian language, in what follows I focus less on what Marvell borrows from these writers than on what he chooses to omit. Marvell's "Ode" may have been politically aligned with English republican writing, but I argue that the “Ode" departs significantly from Milton and Nedham's religious prejudices, airbrushing the anti-presbyterian rhetoric of Milton and Nedham's writings on Ireland and Scotland, to produce representations of the tamed Irish and 'parti-coloured' Pict that are anti-catholic without being anti-presbyterian. ${ }^{12}$ This, I suggest, is an attitude consistent with Marvell's later anti-catholic, but pro-nonconformist, approach to Ireland, in his two-part defence of nonconformity, The Rehearsal transpros 'd (16721673), part one of which offers a damning assessment of John Bramhall's Irish career under Thomas Wentworth, earl of Strafford, the Caroline lord deputy of Ireland (1633-41). ${ }^{13}$ Marvell writes of how Bramhall's attack on 'the Calvinian Doctrines' and insistence on Anglican uniformity had exacerbated existing divisions within Irish Protestantism, creating the conditions that had allowed 'the Irish Rebellion and Massacre' of 1641 to occur. ${ }^{14}$ Reading Marvell's later views on Ireland's religious landscape back into "An Horatian Ode", this article argues that Marvell was more selective in his reading of Milton and Nedham than has been previously recognised, 
and that Marvell's focus on catholic stereotypes of Scots and Irish in the "Ode" implies his refusal to entertain the barbed language of Milton and Nedham's antiPresbyterianism.

\section{Popery, presbytery and English republican writing: Milton's Observations and}

\section{Nedham's Mercurius Politicus}

If religion inflected English responses to Cromwell's Irish and Scottish campaigns, the same was true of Irish and Scottish responses to the religious politics of commonwealth England. 'They say, wee are not all England', Milton writes, attacking what the Belfast presbytery - the 'Scottish Inhabitants of the Province' had written in A Necessary Representation against 'the insolent and presumptuous practises of the Sectaries in England'. But 'we reply they are not all Scotland'. ${ }^{15}$ Milton published his animadversions on the Belfast Representation in May 1649 alongside his Observations attacking the peace articles brokered in Ireland between the royalist, protestant, lord lieutenant of Ireland, James Butler, marquess of Ormond, and the catholic confederation of Kilkenny. Milton's Observations deliberately muddies these religious differences between the English Commonwealth's various catholic and protestant enemies in Ireland, lumping English protestant royalists and Scottish presbyterians together, as 'accomplices and assistants to the abhorred Irish Rebels'. ${ }^{16}$ Similar anti-presbyterian strategies punctuate early issues of Marchamont Nedham's republican newsbook, Mercurius Politicus. Published weekly from 13 June 1650 in the build up to Cromwell's Scottish campaign, Politicus turns Milton's tactic of identifying presbytery with popery in Ireland against the 'high Raunters of Presbyterie' in Edinburgh. ${ }^{17}$ 
Milton's damning assessment of 'the abhorred Irish Rebels' in Observations was in part informed by his reading of the first printed edition of Edmund Spenser's $A$ View of the State of Ireland, prepared by James Ware and printed in Dublin in 1633. That Milton read Spenser's View in Ware's 1633 edition is clear from the several entries in Milton's commonplace book that reflect his admiration for Spenser's brutal solution to the problem of pacifying Ireland. ${ }^{18}$ Spenser, through the person of Irenius, proposes to uproot rebellion through a policy of mass starvation, transforming 'stout and obstinate rebells' into 'anatomies of death' ${ }^{19}$ Yet the suppression of rebellion is only one aspect of Spenser's plans for the 'reformation of that realme', the success of which, he writes, will also be dependent on reforming the laws and offices of English colonial government, on 'planting [...] religion', as well as crops, and on controlling access to the land itself. ${ }^{20}$ Milton shows particular interest in these, Spenser's longterm proposals for colonial reform. Willy Maley's research highlights two relevant entries in Milton's commonplace book, the first concerning Spenser's discussion of 'the wicked policies of divers deputies and governours', the second his 'provision for souldiers after the warrs', 'from p. 84. \&c.' of Ware's edition, Milton notes. ${ }^{21}$ Spenser's discussion of 'some blame thereof in the 'principall governours' roots his list of particular faults in one 'chiefe evill' - that lord deputies exercise a partial and piecemeal authority, reliant on the English Privy Council's support, and subject to censure by 'maligners' who 'deprave and pull back what ever thing shall be begun or intended there'. ${ }^{22}$ These combined pressures create politic governors, who 'will rather winke at some faults, and will suffer them unpunished'. ${ }^{23}$ Spenser's solution is to grant lord deputies a 'more ample and absolute authority' through the appointment of a lord lieutenant, to whom alone the lord deputy would be answerable, and who would be 'no discountenancing of the Lord Deputy, but rather a strengthening of all 
his doings' ${ }^{24}$ In support of these measures, Spenser cites 'Machiavel in his discourses upon Livie, where he commendeth the manner of the Romans government, in giving absolute power to all their Councellors and Governours, which if they abused, they should afterwards dearely answere' ${ }^{25}$

Maley argues that Milton's Observations 'was evidently influenced by a close reading of Spenser's View', and Norbrook notes the possible influence of Spenser's Machiavellian reference on Milton's own praise of Cromwell's future Machiavellian leadership in Observations. ${ }^{26}$ Commissioned in March, Milton's Observations was published 'by Autority' in the same month - May 1649 - that Cromwell was named lord lieutenant of Ireland, and Jim Daems is among those to read Milton's attack on 'those inhumane Rebels and Papists of Ireland' as 'a preemptive justification of Cromwell's brutal Irish campaign' ${ }^{27}$ The Observations also attacks the actions of the royalist lord lieutenant, the marquess of Ormond, who in a letter written in March 1649 to the parliamentarian governor of Dublin, Colonel Michael Jones, had accused England's Independent-led republican government of subverting 'true religion' and establishing 'Anarchy' under the Anabaptist, 'Crumwell'. ${ }^{28}$ Milton responds with withering criticism of Ormond's own 'Irish exploits', contrasting these with the 'eminent and remarkable Deeds' that Cromwell 'in few yeares' has achieved. ${ }^{29}$ His 'valour and high merit many enemies more noble then himself have both honour'd and feard, to assert his good name and reputation', Milton asserts of Cromwell, 'of whose service the Common-wealth receaves so ample satisfaction' ${ }^{30}$ Balancing praise of Cromwell's 'valour' with assurances of his 'service', Milton's language anticipates Marvell's own assessment of Cromwell's achievements in Ireland the following year. Marvell's “Ode” also speaks Miltonically of Cromwell as leader and servant - 'How fit he is to sway', Marvell notes, 'That can so well obey'. ${ }^{31}$ Marvell 
does not just repeat the language of Observations, however; his "Ode" adds weight to Milton's claim that even Cromwell's enemies can 'assert his good name and reputation' by putting these words in the mouths of the 'tam'd' Irish themselves:

They can affirm his praises best,

And have, though overcome, confest

How good he is, how just,

And fit for highest trust;

Nor yet grown stiffer with command,

But still in the republic's hand. ${ }^{32}$

Marvell's 'Irish' here echo Milton's affirmation of Cromwell's fitness 'for highest trust', while Milton himself may in turn have been echoing Spenser's Machiavellian assessment of the ideal Irish governor in A View - one who, Spenser writes, should 'sway' and 'obey' in equal measure, granted 'absolute power', but answerable for abuses of power with their lives.

Marvell was not the only writer in the summer of 1650 to praise Cromwell in Miltonic terms, by the measure of his military 'Deeds'. Marvell's accent on Cromwell's 'industrious valour', and his admiration for Cromwell having taken but 'one year' to tame a nation that had troubled the English for a century or more, is also reflected in Nedham's account of Cromwell's return from Ireland, in the first issue of Mercurius Politicus (6-13 June 1650). ${ }^{33}$ Nedham writes that 'it is the wonder of our Neighbour Nations, that so much should be done in so little time', and that Cromwell's 'Deeds' had earned him the title 'Novus Princeps', a reference, Worden notes, to the new prince - il nuovo principe - who rules by might not birth right, and for whom Machiavelli had originally intended The Prince. ${ }^{34}$ Nedham writes 
admiringly of Cromwell's military prowess - his 'bare reputation', he notes, 'is battery strong enough against the stoutest hearts, and most impregnable Castles' even as his news from Ireland throughout June reveals the realities behind the rhetoric of conquest. ${ }^{35}$ Cromwell's absence has emboldened the confederates, Nedham admits on 8 June, and while he assures readers that 'one Thunder-Clap more will serve to clear all Ireland from infection', his report for 21 June brings news of 'how the bold Rebels came 6000 . in a body out of Ulster' ${ }^{36}$ Cromwell's victory, as Michael Komorowski notes, was by no means assured on his return to London in early June. ${ }^{37}$ Nedham, like Marvell, however, speaks the language of conquest, even as the war in Ireland raged on. Politicus reports these confederate advances in muscular prose, revealing a sneering disregard for 'those Brutes of the Nation', hunted 'like Deer in a Forrest', and driven 'into a Bogg, where they were pursued till they were lost all in a fogg' ${ }^{38}$ The language is Spenserian, for $A$ View also applies the epithets 'brutish' and 'barbarous' to the native Irish and Old English and characterises Irish rebels as 'a flying enemie, hiding himselfe in woodes and bogges'.${ }^{39}$ Patricia Coughlan writes that Spenser applied to the Irish 'pre-formed notions about the incivility of those without a native urban culture' - notions Spenser adopted from classical sources such as Herodotus's description of the nomadic Scythians, whose savagery Herodotus deliberately contrasts with the civility of urban Athenian culture. ${ }^{40}$ Spenser, as Richard McCabe writes, uses Herodotus to inform comparisons between Irish and 'Scythian customes', his aim being not merely to suggest that the Irish were as savage as the Scythians but that the Irish were themselves originally Scythian. ${ }^{41}$ So too were the Scots, Spenser maintains: for the Scythians had arrived 'in the North parts of Ireland, where some of them after passed into the next coast of Albine, now called Scotland' ${ }^{42}$ Spenser forges a history of ancestral relations 
between 'the wilde Scotts' and 'naturall Irish' and argues that this pan-Gaelic alliance continues to operate against New English interests in late Elizabethan Ireland. ${ }^{43}$ Spenser was evidently writing with recent events in mind, for the summers of 159495 had seen armed rebellions by catholic earls, first in Scotland, under Huntly and Erroll, then in Ulster under the earl of Tyrone. ${ }^{44}$

A View therefore traces a geography of barbarity that extends from the 'naturall Irish' to the 'wilde Scotts', two nations as related by blood as by their 'brutish' religion - for the Irish, as the Highland Scots, 'be all Papists in their profession, but $[\ldots]$ blindly and brutishly informed' ${ }^{45}$ Equally barbarous is the Old English catholic community in Ireland, who as Irenius asserts have 'degenerated and growne almost mere Irish', taking on the 'barbarous rudenes' of Irish language, customs, and religion. ${ }^{46}$ Although twice noting that he has 'little [...] to say of religion', Irenius nevertheless recommends that Catholicism be uprooted in Ireland through a two-pronged approach. ${ }^{47}$ First, by cutting off the two-way traffic between Ireland and the catholic seminaries 'beyond the sea', for the seminaries send Jesuits to Ireland, or make Jesuits of the sons of Old English families, who 'doe more hurt and hinderance to religion with their private perswasions then all the others can doe good with their publique instructions' ${ }^{48}$ Second, Irenius recommends measures to re-edify churches and increase church livings, as first steps towards re-establishing the established church in Ireland - for 'godly teachers' can never work a reformation in Ireland unless adequately recompensed with 'meete maintenance'. ${ }^{4}$

Spenser's 'rebarbatively negative' characterisation of the Irish was resurrected with vitriol in English responses to the 1641 Irish Rebellion. ${ }^{50}$ Depositions reporting catholic violence against the New English in Ireland were quickly escalated in the London press, culminating in Sir John Temple's sensationalised The Irish Rebellion 
(1646), the 'standard Protestant interpretation' of the uprising. ${ }^{51}$ Temple cements two key 'facts' about the Rebellion that had been circulating since at least the publication of Henry Jones' official enquiry into the causes of the Rebellion, commissioned by the Long Parliament, and published as A Remonstrance in March 1642: that the rebellion was the product of an international papist conspiracy, 'intending the utter extirpation of the reformed Religion, and the professors of it', and that the 'cruelties' and 'depredations' of the rebels were such as would shame even 'the most barbarous and heathenish Nations',52 To the standard Spenserian stereotype of the bog dwelling papist brute, therefore, English protestant responses to the Irish rebellion brought the language of righteous outrage and religious retribution. As Nedham writes, Irish rebels must 'drink the same measure of blood which they gave the English, in the rise of their Rebellion' ${ }^{53} \mathrm{He}$ and Milton both write of Cromwell's campaign in Ireland as an anti-catholic crusade - an opportunity to enact a Spenserian 'reformation of that realme'. 54

It is with Spenser's plans for the 'planting of religion' in mind, therefore, that Milton extends his praise of the Machiavellian governor to a consideration of the governor's role in the war against Irish Catholicism. ${ }^{55}$ To Ormond's claim that independents in England's commonwealth government were 'the Subverters of true Religion', Milton responds by contrasting Ormond's record in Ireland with the anticatholic ordinances of the English parliament. ${ }^{56}$ Ormond, Milton writes, has made peace with catholic confederates, and so 'of all Protestants may be calld most justly the Subverter of true Religion'. 'Parlament', on the other hand, are 'the maintainers and defenders of true Religion', for they have not 'countenac'd Popery or Papists, but have every where brok'n their Temporall power, thrown down their public Superstitions', while 'encourag[ing] all true Ministers of the Gospel' ${ }^{57}$ Milton here 
directs his praise to the work of the parliament in England, not that of the lord lieutenant in Ireland. However the context of his remarks - an attack on Ormond's failings as lord lieutenant - implies the translatability of parliament's anti-catholic religious policy in England to the situation in Ireland under its new lord lieutenant, Cromwell. Framed through his description of the English parliament's achievements for 'true Religion', the religious 'reformation' that Milton encourages Cromwell to enact in Ireland is broadly Spenserian in its emphasis on stifling the 'Temporall power' of 'Popery' and 'Papists', and on supporting 'true Ministers of the Gospel' financially and through political protection. Milton's argument that the state should exercise minimal control over matters of conscience, departs from Spenser's own religious views. Recent research reveals Spenser to be a moderate, non-separating puritan whose writings attack Presbyterianism and insist on conformity to the established church, as Irenius' jibe at 'some of our late too nice fooles' who criticise the 'seemely forme, and comely order of the Church' reveals. ${ }^{58}$ But Spenser and Milton find common ground in their identification of Irish papists as the common enemy of (New) English Protestantism, and their acknowledgement of the need for Machievallian leadership in Ireland, to uproot rebellion 'by the sword', and plant 'true Religion' in its stead. ${ }^{59}$

Spenser and Milton both attacked presbyterians, although both for very different reasons. For Spenser, presbyterians were separatists who threatened the uniformity of the established, episcopal, church. For Milton, writing in an era when the established church had been all but disestablished, it was now presbyterians who were insisting on national uniformity, and who in so doing were threatening the religious freedoms to which Milton was committed. It is not the ideological, so much as rhetorical differences between Spenser and Milton's approaches to Presbyterianism 
that I here want to emphasise, however. Irenius' attack on 'too nice fooles' in A View comes in a passage recommending rebuilding ruinous Irish churches 'in some better forme, according to the churches of England'. Irenius argues that 'the outward shew' of churches would 'drawe the rude people to the reverencing and frequenting thereof', and that their 'seemely forme' was thus a necessary first step in converting the Irish to Protestantism. 'Godly teachers' would 'bring them to the true understanding' of religion, but what good was preaching if you couldn't entice 'the rude people' to the pulpit? Irenius' jibe at those who would make much of 'outward shew' therefore makes clear that such 'too nice', or overly fastidious, objections, by discouraging 'the rude people' from attending church, detracts from the greater goal of converting 'Papists' to Protestantism. But Irenius' accent on 'our late too nice fooles' also acknowledges a place for these 'fooles' within the wider protestant community; indeed, Irenius' language actively encourages their inclusion, the use of 'our' rhetorically uniting factions whose ideological opposition to aspects of ecclesiastical 'forme' tends otherwise to divide. ${ }^{60}$ Spenser's point is that separating puritans and presbyterians make trouble for the church, dividing the protestant community in Ireland at a time when it should be uniting against Catholicism.

Milton also thinks of presbyterians as fools. His Observations pillories the Belfast presbytery as 'blockish Presbyters' for their writing against 'the Sectarian party in England', and it does so for reasons similar to Spenser's, arguing that their 'unexampl'd virulence' against fellow protestants ultimately supports the cause of Irish Catholicism, making them 'accomplices and assistants to the abhorred Irish Rebels' because colluding in their 'war against the Parlament'. ${ }^{61}$ Milton, however, not only identifies the Belfast presbyterians with the catholic cause of 'Irish Rebels'. In Observations, Milton also aligns this particular presbytery, sitting 'so haughtie in the 
Pontificall See of Belfast', with 'Popery' more generally, arguing that their writing reveals them to be no better than papists in their claim to wield 'an absolute and undepending Jurisdiction' over the state, as 'the Pope hath for many Ages done' ${ }^{62}$ And not only in Belfast are presbyterians guilty of popery; that presbyterians are no better than papists is a claim Milton also extends to Presbyterianism more generally, animadverting that 'Presbyteriall government' is as 'the Popish and Prelaticall Courts, or the Spanish Inquisition' ${ }^{63}$ Milton's elision of presbytery and popery may be rhetorical, a means to shame the Scots presbytery at Belfast to their senses, yet Milton's language nevertheless does something quite different to Spenser's jibe at 'our fooles' in Ireland: Spenser encourages unity, Milton division. By lumping Scots presbytery, Anglican prelacy, and Irish popery together, the rhetoric of Observations divides 'true Protestants' in England from those, like Ormond, or the Belfast presbyterians, who 'would be thought a Protestant Assembly' ${ }^{64}$ The Observations not only chides the 'blockish Presbyters' of Belfast, therefore; it elides this Scots presbytery with the common catholic enemy of English protestants. In the process, it links animosity towards Presbyterianism with animosity towards Scotland in ways that would have implications for how the Commonwealth chose to conduct its propaganda war with Scotland in the summer of 1650.

Joad Raymond argues that Milton's anti-Presbyterianism was fuelled by 'his suspicion of and antipathy to the Scots', and while Maley and Swann are right to note the more 'nuanced' perspective on Scotland that Milton's respect for John Knox's Presbyterianism and republicanism reveals, in Observations Milton nevertheless connects Belfast presbyterians with 'the Scottish inhabitants of that province' in ways calculated to combine religious with national prejudice. ${ }^{65}$ Milton draws on Spenser's claims for the consanguinity between Highland Scots and Ulster Irish - for 'doe we 
not all know', Irenius asks, 'that those which now are called the North Irish, are indeed very Scottes'? - to argue in Spenserian terms that the Belfast presbyterians are no better than 'High-land theevs and Red-shanks', a coinage Milton may well have borrowed directly from Spenser's View, which notes how the Ulster O'Neills have historically had 'all succours of those Scottes and Redshankes'. ${ }^{66}$ Spenser himself borrowed 'Redshank' from Holinshed's Chronicles (1587), where it is used with reference to the 'Picts', whom Holinshed writes 'were settled in this Ile long before the $[\ldots]$ coming of the Scots', and whom Mamertinus 'calleth [...] Redshankes and Pictones' ${ }^{67}$ Holinshed distinguishes Picts from Scots, whom he, like Spenser, describes as 'a people mixed of the Scithian and Spanish blood', who 'arrive[d] here out of Ireland'. Holinshed also assumes 'Scithian' origins for the Picts, however, who in any event had combined with the Scots 'against the Britains [...] not long before the beginning of Cesars time'. ${ }^{68}$ Spenser also blurs distinctions between 'Scottes and Redshankes', arguing that both 'succour' the Ulster Irish in their campaigns against English colonial rule. Milton follows suit, flinging both epithets at the Belfast presbytery in ways again calculated to associate the presbyterians with papists, and here specifically with the Scottish catholic clans whose collusion with the Ulster Irish had so animated Spenser in the 1590s.

Milton's anti-presbyterian language therefore mines a seam of English antiScottish and anti-catholic prejudice that draws on Spenser's own 'anti-Scottish' stereotypes. ${ }^{69}$ A year later, the same jingoistic jibes against Scottish presbyterians - in Ulster, as well as Edinburgh - would reappear in Nedham's Politicus, the mouthpiece of the republican propaganda war against Scotland in summer $1650 .{ }^{70}$ Nedham's first issues mingle stock parodies of Scottish poverty and proclivity for 'Mackerel' eating with Miltonic parries at 'the common cause of Scotch Presbyterie, and Irish 
Popery'. ${ }^{71}$ In Ireland, he writes, 'the bold Rebels' are 'called good Subjects' by the future king, Charles II, 'the bonny Lad of Scotland', while the same catholic rebels call on 'the Scotish Priests' of the presbyteries to pray for their victory against the Cromwellian army. ${ }^{72}$ The Scottish kirk, Nedham writes, is as 'haughtie' in its handling of civil matters as Milton's Belfast presbytery (Nedham calls on readers to judge "whether the Kirk be not bravely inthroned in Scotland; when she destines whom she pleases to death'), and he argues that the kirk wears only a mask of royalism, its support for Charles II a means to 'inthrone' itself 'on this side Berwick', in England as well as Scotland. ${ }^{73}$

Milton inherits Spenser's language of Ireland: his anti-Catholicism, his horror of rebellion, and his suspicion that Scots and Redshanks were colluding with the Ulster Irish against the English. But it is Milton's application of this language to the Scots presbytery at Belfast that marks a shift in Observations from the religious geography of A View, a shift later replicated in Politicus. Similar claims appear in the English army pamphlets that were printed in July-August 1650 to justify the army's invasion of Scotland and parry the kirk's counterblasts against 'the Sectaries of England' ${ }^{74}$ The authors of $A$ Vindication of the Declaration of the Army of England, for example, answer the General Assembly's Short Reply (reprinted in the same pamphlet) by returning to Milton's analogy between popery and presbytery, noting the Scottish kirk's 'Spiritual Tyranny \& outward Violence [...] not unlike that under the Inquisition'. ${ }^{75}$ No longer Spenser's English 'fooles', by 1650 presbyterians had become England's Scottish enemies, aligned with the politics of Irish 'rebel' confederates and the religion of Irish catholics. Milton's presbyterians were the new 'Red-shanks' worrying the English commonwealth, their seat the General Assembly 
at Edinburgh, their aim to wage war 'against the Britains', as their ancestors, the Scots and Picts of Caesar's day, had done.

\section{The religious geography of Marvell's "An Horatian Ode"}

Marvell's "Horatian Ode" also trades in the anti-Scottish propaganda of Politicus and other republican writing produced in the summer of 1650. With Cromwell 'march[ing] indefatigably on' towards Berwick, Marvell writes,

The Pict no shelter now shall find

Within his parti-coloured mind;

But from his valour sad

Shrink underneath the plaid:

Happy if in the tufted brake,

The English hunter him mistake,

Nor lay his hounds in near

The Caledonian deer. ${ }^{76}$

'The Pict', as we have seen, is a synonym for Spenser and Milton's 'Redshank', and Marvell follows both in assuming an alliance between 'Highland' Scots and Pictish Redshanks, dressing his Pict in the 'plaid', or tartan kilts, associated with Highland clans. ${ }^{77}$ Marvell's Pict is thus a composite, 'parti-coloured' Scotsman, woven, plaidlike, from the warp and weft of Scotland's history of Scots and Picts, and here combining into one negative stereotype - a figure who spans the Highland/Lowland divide, just as Spenser and Milton blur distinctions between 'Scottes and Redshankes' when acknowledging their combined collusion with the Ulster Irish against English colonial rule. Marvell's Pict also emerges in the first stanza above in Spenserian 
guise, an embodiment of Spenser's 'Scythian' stereotype of 'the wilde Scotts' whom, as Irenius writes, 'are indeed the very naturall Irish' ${ }^{78}$ This stereotype Milton mobilises for his attack on catholic 'Red-shanks' in the Belfast presbytery, and this in turn anticipates Nedham's conflation of popery with presbytery, in his jibes at 'Scotish Priests' in Ireland and Edinburgh. It has been argued that Marvell also intended his Pict as an anti-presbyterian caricature, and indeed there is nothing in the first stanza above to oppose this reading. ${ }^{79}$ Marvell's Pict is rooted in Spenser's anticatholic stereotypes of Irish-Scottish savagery, yet like Milton, Marvell might have intended this stereotype as a snub at the presbyterian kirk, implying that the Scottish kirk was just as 'blindly and brutishly informed' in its religion as Spenser's Irish papists, or Milton's Ulster presbyterians.

Perhaps; but if we turn from the first to the second stanza quoted above, the idea of Marvell's Pict as a vehicle for anti-kirk satire becomes more difficult to sustain. Here, the Pict is hunted like 'the Caledonian deer' through terrain thick with 'brake' or bracken, a description that, as John Kerrigan notes, places Marvell's Scotsman 'beyond the Highland line, among the followers of Montrose' ${ }^{80}$ James Graham, first marquess of Montrose, had been the enemy of the kirk since he had defected to the royalist cause in winter 1644-45, leading a combined troop of Highlanders and Irish to a string of victories against the covenanters in the Scottish Highlands. Returning to the Highlands from royalist exile in the Low Countries in 1649-50, Montrose tried to repeat his earlier military successes against Scotland's covenanting regime, this time fighting for the new king, Charles II, following the collapse of the king's discussions with the covenanters in May 1649. Montrose's campaign was doomed from the outset, however, for even Montrose recognised that he was merely a pawn in the king's plans to force the covenanters back to the 
negotiating table. Montrose's own endgame came soon after with defeat and capture at Carbisdale (April 1650), and then execution at Edinburgh on 21 May $1650 .{ }^{81}$ In the early issues of Politicus, Nedham makes much of Montrose's decapitated head, displayed on the Edinburgh Tolbooth. ${ }^{82}$ For Nedham, this head symbolised 'the wicked partiality and Hypocrisie of the Presbyterians', who could condemn Montrose - the actor of this royalist uprising - in the same breath as they courted its author, the new king, one 'more guilty than he'. ${ }^{83}$

Marvell might have intended his 'parti-coloured' Pict as an anti-presbyterian reference, a jibe, with Nedham, at the 'wicked partiality [...] of the Presbyterians'. But, standing in the Highlands, the partiality of Marvell's Pict would seem more plausibly to echo Scottish presbyterian accusations against Montrose, who was himself accused at his trial of hypocrisy and partisanship, as a turncoat to the covenanting cause ${ }^{84}$ Had Marvell really intended his Pict to pillory Scottish Presbyterianism, the most sensible place to have located him, in a poem written over the summer of 1650, was not the Highlands, but Edinburgh, the backdrop to Nedham's presbyterian satire and scene of the kirk's executive power (and Montrose's execution). By choosing to set his Pict in the Highlands, therefore, Marvell, as Kerrigan suggests, actually 'deflects hostility from Lowland Presbyterians' ${ }^{85}$ In the process, Marvell signals his departure from the antipresbyterian rhetoric of Milton and Nedham, suggesting that while the "Ode", as Worden and Norbrook argue, is a poem invested in the politics of English republicanism and its campaigns in Ireland and Scotland, it is less committed to the religious propaganda of republican writing and its attempts to blacken presbytery with the name of popery. ${ }^{86}$ 
Marvell's representation of the Irish also lacks anti-presbyterian bite, for like the Pict, the Irish stand in Marvell's poem as Spenserian stereotypes of Scythian barbarism - a barbarism that Cromwell's conquest has now 'tamed'. Marvell's language of 'taming' likens the Irish to Nedham's 'Brutes of the Nation', suggesting that the term 'Irish' is used exclusively in the "Ode" of those actors in the rebellion of October 1641 - Milton's 'inhumane Rebels and Papists of Ireland'. Marvell does not extend his characterisation of these brutish rebels to a satire on those other 'accomplices and assistants to the abhorred Irish Rebels' - the English royalists under Ormond and the Scots presbyterians at Belfast - that Milton attacks in Observations; neither does he emphasise, with Nedham, 'the common cause of Scotch Presbyterie, and Irish Popery', or quip at the involvement of 'Scotish Priests' in Ireland's confederate wars. ${ }^{87}$ Milton and Nedham both flatten out the religious differences between Ireland's various 'rebel' factions, lumping popery and presbytery together, yet they also acknowledge ethnic divisions between Scots and English on the one hand, and Irish 'brutes' on the other, and while they imply that presbyterians are as 'brutishly informed' as Irish papists, they never extend the Irish epithets of barbarity to the Scots and English themselves. The fact Marvell only trades in this language of Irish barbarity, therefore, leaves no nuance in his characterisation of the Irish for anything approaching Milton and Nedham's republican satire on the religious similitudes between 'Scotch Presbyterie, and Irish Popery'. Marvell reduces the plurality and complexity of Ireland's competing religious voices to a single, univocal 'confession' of Cromwell's greatness. When the 'Irish' speak in the poem to 'affirm his praises best', therefore, it is only the voice of the 'inhumane' Irish papists that we hear. 
For all Marvell's republican admiration for Cromwell, therefore, the "Ode" is profoundly ambivalent about the religious dimensions of republican propaganda. The poem ends with Cromwell 'March[ing] indefatigably on' towards Berwick, yet the nature of the enemy he will encounter in Scotland remains unclear. Readers of Politicus and the army pamphlets circulating in the summer of 1650 are left in no doubt that Cromwell's enemy is the spiritual tyranny of the Scottish kirk and its intention to impose Presbyterianism 'on this side Berwick'. Readers of the "Ode", on the other hand, are confronted, in Marvell's Pict, with a figure who frustrates these anti-presbyterian expectations. Standing in the Highlands, dressed in tartan plaid, Marvell's Pict dissolves into a parody of Spenser's 'Scottes and Redshankes' - a plausible embodiment of Montrose's Highlanders and their alliance with the Irish in the Highland campaigns of 1644-45, and thus a reminder of Spenser's fears over the Celtic consanguinity and catholic collaboration between Irish and Highland clans. Marvell's 'Irish' also evoke Spenserian fears of Irish catholic rebellion, the "Ode" in this sense echoing the Spenserian language of Milton's Observations and Nedham's Politicus, yet at the same time departing from both in the studied simplicity of Marvell's anti-catholic stereotype, which leaves no room for republican attacks on the 'Scotch Presbyterie' in Ulster and its hostility towards English Independency and the English republican cause. Both Milton and Nedham engage in forms of protestant infighting, acknowledging 'Scotch Presbyterie' alongside 'Irish Popery' as the common enemy of English Protestantism. Marvell avoids these internecine battles, representing the English commonwealth's enemies as primitive stereotypes of Scythian barbarity and Celtic Catholicism - straw men of incivility, to be hunted like deer and tamed like beasts. 
Such caricatures may simply reflect Marvell's prejudices towards the inhabitants of Britain's 'Celtic fringe', but given what critics have noted about Marvell's engagement with the Machiavellian language of Milton and Nedham elsewhere in the "Ode", I would suggest that his deviation from their anti-presbyterian position on Scotland and the Ulster Scots seems less a reflection of Marvell's views on Scottish and Irish Catholicism than of his views on Milton and Nedham's antipresbyterianism. To read the "Ode" alongside Milton and Nedham's attacks on Presbyterianism in Scotland and Ireland is thus to reveal, if not Marvell's support for the Scottish presbyterian position (which may well, for Marvell, have seemed too 'tyrannous' in its insistence on presbyterian conformity), then at least his belief that protestants should not make enemies of each other. Identifying a catholic, Celtic enemy helps heal internecine divisions between Britain's protestant communities; aligning Scottish presbytery with Irish popery serves only to aggravate these divisions.

Marvell's representation of the British-Irish archipelago's catholic, Celtic margins also has implications for our reading of 'restless Cromwell', the figure at the centre of "An Horatian Ode". ${ }^{88}$ Worden and Norbrook both read Marvell's Cromwell in a Machiavellian light, arguing that Marvell commends Cromwell's military ambition, his 'industrious valour', at a time when the English republic, beset by enemies in Britain, Ireland, and mainland Europe, needed a Novus Princeps strong enough to stand up to the forces of royalism, and silence, with military might, the continued clamours of 'the ancient rights' ${ }^{89}$ However the recognition that Marvell trades in anti-catholic stereotypes of the Scots and Irish qualifies considerably Marvell's Machiavellian preparedness to applaud Cromwell's military muscle, implying as it does that Marvell frames Cromwell's campaigns in these countries as 
exclusively anti-catholic crusades - a significant departure from Milton and

Nedham's more partisan concern to identify Presbyterianism, alongside popery, as the royalist enemy of English republicanism. Marvell places limits on the ascent of Cromwell's 'active star', his poem urging military activity only insofar as this is directed outwards, not at protestant royalists in England, Ireland, and Scotland, but at the caricatures of Celtic, catholic incivility that people the margins of Marvell's 'kingdoms old' ${ }^{90}$ Cromwell's enemies in Britain and Ireland are in this sense of a piece with his catholic enemies abroad, the kingdom of France, and the kingdoms, duchies, and papal states of Italy whose emancipation Marvell briefly imagines in the "Ode":

A Caesar he ere long to Gaul,

To Italy an Hannibal,

And to all states not free

Shall climacteric be. ${ }^{91}$

Sandwiched directly between his poem's celebration of Cromwell's Irish conquest - 'What may not others fear, | If thus he crowns each year?' - and its anticipation of Cromwell's military success over the plaid-wearing 'Pict', the above lines invite readers to connect Cromwell's conquests in Britain and Ireland with his crusading efforts to emancipate other western European nations from their subservience to papal, as well as regal, power. ${ }^{92}$ Blair Worden is among critics to read Cromwell's intended emancipation of France and Italy in a primarily political light, connecting the above lines with those of Marchamont Nedham, who in The case of the commonwealth of England, stated (May 1650), observes 'how the Worm works in many parts of Europe to cast off the Regall yoke' ${ }^{93}$ This conception of Cromwell's European campaigns as directed against 'the Regall yoke' is itself implicit in 
Marvell's choice of similes: as a latter-day Julius Caesar, Cromwell's conquests abroad would help consolidate his - and the English republic's - 'forcèd power', its de facto right to rule, just as Caesar's conquest of Gaul had strengthened both the Roman republic and his own political career within it. ${ }^{94}$ Marvell's identification of the catholic powers of France and Italy as the particular battlegrounds of Cromwell's wars abroad also helps convey strong religious motivations for these European campaigns, however. These are crusading connotations to which Marvell returns four years later, in "The First Anniversary of the Government under His Highness the Lord Protector" (December 1654-January 1655). In this poem, 'Angelic Cromwell' is depicted in an explicitly millenarian light, as one who

$[\ldots]$ in dark nights, and in cold days alone

Pursues the monster thorough every throne:

Which shrinking to her Roman den impure,

Gnashes her gory teeth; nor there secure..$^{95}$

Cromwell's target here is less the 'regal yoke' of western European princes as the papal 'monster' who occupies 'every throne', and who itself yokes these 'Unhappy princes' to the ignorance and 'error' of Roman doctrine: 'Hence still they sing hosanna to the whore, | And her whom they should massacre adore'. ${ }^{96}$

Writing of Marvell's 'Angelic Cromwell', Derek Hirst positions the poem's millenarian language as Marvell's considered response to the particular threat posed by fifth monarchists to the stability of Cromwell's protectorate around the time of its first anniversary in December $1654 .{ }^{97}$ Leading fifth monarchists like Christopher Feake and John Simpson, both mentioned by name in "First Anniversary" (1. 305), had taken advantage of the protectoral anniversary to preach against Cromwell and the protectorate, which Feake denounced as 'another kind of Kingship' and a 'NEW 
UNEXPECTED TYRANNY', no different from Antichrist's other 'ten Horns, or Kings', and thus no more to be suffered, but rather shaken off and opposed. ${ }^{98}$ Hirst argues that in "First Anniversary" Marvell plays the fifth monarchists at their own game, applying their millenarian language to construct Cromwell, not as a horn of Antichrist, but as 'the great captain' whose pursuit of the 'monster' - the beast of Revelation - would in fact help herald the dawn of the promised millennium. ${ }^{99}$ Marvell's millenarian language is thus calculated to persuade fifth monarchists to drop their 'apocalyptic onslaughts on Oliver', Hirst writes, this despite the fact that elsewhere Marvell's poem derides fifth monarchists as a 'race most hypocritically strict! | Bent to reduce us to the ancient pict'. ${ }^{100}$ Marvell's reference to 'the ancient pict' here recalls the occurrence of that figure in the "Ode", although with its accent on 'ancient', the Pict in "First Anniversary" is far removed from the contemporary, Highland setting of the earlier poem. It is the Pict's proverbial nakedness, not his Highland plaid, that Marvell emphasises in "First Anniversary", as his subsequent allusion to sectaries 'act[ing] the Adam and Eve' makes clear. Marvell's former jibes at Highland barbarity here morph into an 'identification of radicalism and native primitivism', as Marvell's later poem responds to new instabilities in the English commonwealth by training its sights on new sectarian targets. ${ }^{101}$ In "First Anniversary", sectaries who actively undermine Cromwell's protectorate are as unwelcome in commonwealth England as the catholic princes who 'sing hosanna to the whore'.

Yet there are also important differences between the treatment of papists and sectarian 'picts' in "First Anniversary", for while fifth monarchists are the target of Marvell's satire, it is only the papist 'monster' whom Marvell imagines Cromwell actively 'pursu[ing]' in battle 'thorough every throne'. Unlike Milton and Nedham, 
who blur distinctions between 'Scotch Presbyterie' and 'Irish Popery' in ways calculated to identify both as legitimate targets of English swords, Marvell's verbal attack on fifth monarchists turns from swords to words. This is a poem which, rather than fan the flames of division, seeks to appease protestant radicals, and to reconcile them with 'Angelic Cromwell' - a poem which envisions the architecture of a protectorate made stronger through 'the resistance of opposèd minds' ${ }^{102}$ Edward Holberton writes of "First Anniversary" that the poem "breaks with established monarchical and republican conceptions of the English constitution' to celebrate Cromwell as architect of a third way, an English protectorate of checks and balances, 'structured vigilantly against internal and external dangers'. ${ }^{103}$ Holberton sketches a very different political terrain for this poem from the binaries of royalism versus republicanism that tend to animate critical approaches to "An Horatian Ode", and by highlighting Marvell's emphasis in "First Anniversary" on the novelty, as well as necessity, of the protectorate, Holberton also departs from conventional readings of "First Anniversary" as a republican 'critique' of 'the trend towards monarchy' exemplified in Edmund Waller's Augustan Paneqyrick to Cromwell (1655). ${ }^{104}$ Yet whatever the politics of "First Anniversary" and its departures or otherwise from the republicanism of the "Ode", it should be emphasised that the respective religious geographies of these poems differ little from each other. Both poems pit an English republic founded on the principles of liberty of worship to all but 'Popery or Prelacy', against the error and ignorance of catholic regions in Britain, Ireland and 'all states not free'. ${ }^{105}$ In so doing, both poems accord a key role to Cromwell as a military leader - 'the great captain' of the commonwealth. At the same time, however, both can only contemplate Cromwell with 'sword erect' when this sword is directed, not 
inwards at presbyterians, fifth monarchists, or other protestant communities, but outwards, at the common, catholic enemy of them all. ${ }^{106}$

Marvell's catholic caricatures of Scots, Irishmen, and 'Unhappy princes' in mainland Europe thus help deflect attention from unseemly infighting among protestant communities in Britain and Ireland - a careful avoidance of internecine strife that in this sense anticipates Marvell's later commitment to the cause of religious toleration for protestant beliefs and practices outside the established church. Marvell's tolerationism is particularly manifest in his controversial writings from the 1670s that attack the Anglican insistence on conformity to the established church, yet I would argue that these are attitudes nevertheless consistent with the religious geography of the "Ode" and Marvell's other Cromwellian poems from the 1650s. ${ }^{107}$ When two decades later Marvell returns to Ireland in The Rehearsal transpros' $d$, it is to revisit the religious context behind the Irish Rebellion that Cromwell had 'tamed' in the "Ode". In Rehearsal, Marvell disputes Samuel Parker's assessment of John Bramhall's Irish career, first under Thomas Wentworth, later earl of Strafford, then, after the Restoration, as archbishop of Armagh. Where Parker writes that Bramhall had showed 'a mind large and active enough to have managed the Roman Empire', Marvell counters that, at a time when 'the Ecclesiastical Differences in our own Nations' were rife, Bramhall might have spent less time 'managing the Roman Empire', more 'the Peace of his own Province and Country'. ${ }^{108}$ Bramhall might, like the 'good Primate' his metropolitan, James Ussher, have set out to 'abate ... our Episcopall Grandeur', Marvell continues, and 'reduce the Ceremonious Discipline in these Nations to the Primitive Simplicity'. ${ }^{109}$ Bramhall, however, was an acolyte of Archbishop Laud, not Ussher, and like Laud 'a zealous and resolute Assertor of the Publick Rites and Solemnities of the Church'. In Marvell's eyes, Bramhall's zeal for 
'external neatness' had had only negative results, striking a blow for protestant unity by further exacerbating 'Ecclesiastical Differences' among Irish protestants. ${ }^{110}$ 'What then was this that Bishop Bramhal did?', Marvell asks.

Did he, like a Protestant Apostle, in one day convert thousands of the Irish Papists? The contrary is evident by the Irish Rebellion and Massacre, which, notwithstanding his Publick Employment and great Abilities, happened in his time. ${ }^{111}$

It was not just that Bramhall had misapplied his 'Publick Employment and great Abilities' by channelling these energies towards the eradication of protestant nonconformity. It was that, by turning his antagonism inwards, against 'the Calvinian Doctrines', Bramhall had turned his back on the common, catholic enemy, thus creating the conditions that had allowed the Irish Rebellion of 1641 to ignite.

Marvell's religious position in Rehearsal is, then, a recapitulation of what we might infer of Marvell's earlier position on the anti-Presbyterianism of English republican writing in the "Ode", insofar as the "Ode", like Rehearsal, also refocuses its readers' attention on 'the Irish Papists' that it was left for Cromwell to conquer, because Bramhall had neglected to convert. Milton, too, was guilty of diverting his protestant zeal away from 'Irish Papists', for the rhetoric of Observations incites as much anti-catholic animosity towards the 'blockish Presbyters' of Belfast as towards 'the abhorred Irish Rebels' themselves. The "Ode" writes from the perspective of the 'Protestant Apostle' that Marvell would later chide John Bramhall for failing to be, a perspective that attacks the kirk-baiting of Milton and Nedham in 1649-50 just as much as it pillories ‘the Irish Bishops Tyranny' over protestant nonconformists some two decades later. Cromwell's soldiers wrote of their march to Scotland in summer 1650 that they went to battle 'with the Covenant on the tops of our Pikes'. ${ }^{112}$ Marvell, 
significantly, removes kirk and covenant from the religious geography of "An Horatian Ode". The final lines of the "Ode" call on Cromwell to "keep thy sword erect', but the poem elsewhere directs Cromwell's sword at 'brutish' papists - the barbarous Irish and kilted Pict - not at presbyterians, however 'popish' Milton and Nedham claim them to be. Although the execution of Charles I is the most 'memorable scene' of Marvell's poem, the poem also draws attention to its - and the English commonwealth's - Celtic margins. Marvell's generation of readers must have found plenty to reflect on here; so too, I would suggest, might we.

\section{Bibliography}

Anon. A Short Reply unto a Declaration entitled the Declaration Entitled, the Declaration of the Army of England upon their march into Scotland. Together with a Vindication of the Declaration of the Army of England Upon their march into Scotland. London: John Field for Francis Tyton, 16 August 1650.

Baker, David J. Between Nations: Shakespeare, Spenser, Marvell, and the question of Britain. Stanford, CA: Stanford University Press, 1997.

Baker, David J. "Britain Redux.” Spenser Studies 29 (2014): 21-36.

Canny, Nicholas. Making Ireland British, 1580-1650. Oxford: Oxford University Press, 2001.

Coleman, David. "Introduction: Regional religions and archipelagic aesthetics." In Region, Religion and English Renaissance Literature, edited by David Coleman. 1-11. Aldershot: Ashgate, 2013.

Coolidge, John S. “Marvell and Horace.” Modern Philology 63 (1965): 111-120

Corns, Thomas N. “Milton's Observations Upon the Articles of Peace: Ireland under English Eyes." In Politics, Poetics, and Hermeneutics in Milton's Prose, edited by D. Loewenstein and J. Grantham Turner. 123-34. Cambridge: Cambridge University Press, 1990

Coughlan, Patricia. "“Cheap and common animals': The English anatomy of Ireland in the seventeenth century." In Literature and the English Civil War, edited by 
Thomas Healy and Jonathan Sawday. 205-23. Cambridge: Cambridge University Press, 1990.

Cromwell, Oliver. The government of the Common-wealth of England, Scotland, \& Ireland ['The Instrument of Government']. London, William du-Gard and Henry Hills, 1653).

Daems, Jim. “Dividing Conjunctions: Milton's Observations upon the Articles of Peace.” Milton Quarterly 33.2 (1999): 51-55.

Darcy, Eamon. The Irish Rebellion of 1641 and the Wars of the Three Kingdoms. Woodbridge: Boydell, 2013.

Dzelzainis, Martin, ed. The Rehearsal Transpros'd. In Prose Works of Andrew Marvell, edited by Annabel Patterson, et al., 2 vols. New Haven: Yale University Press, 2003, I: 1-203.

Everett, Barbara. "The Shooting of the Bears: Poetry and Politics in Andrew Marvell". In Andrew Marvell: Essays on the Tercentenary of his Death, edited by R. L. Brett, 62-103. Oxford: Oxford University Press, 1978.

Fairfax, Thomas. Short Memorials of Thomas Lord Fairfax. Written by Himself, edited by Brian Fairfax. London: for Ri[chard] Chiswell, 1699.

Feake, Christopher. The oppressed close prisoner in Windsor-Castle. London: L. Chapman, 1655 [i.e. 1654].

Grant, Ruth. "George Gordon, sixth Earl of Huntly, and the politics of the CounterReformation in Scotland, 1581-1595." Ph.D. diss., University of Edinburgh, 2010.

Gribben, Crawford. "Polemic and Apocalyptic in the Cromwellian Invasion of Scotland." Literature \& History 23.1 (2014): 1-18.

Guiseppi, M. S., ed. Calendar of the State Papers relating to Scotland and Mary, Queen of Scots, 1547-1603, vol. XII (1595-1597). London: HMSO, 1952.

Hadfield, Andrew. Shakespeare, Spenser and the Matter of Britain. Basingstoke: Palgrave Macmillan, 2004.

Hirst, Derek. “"That Sober Liberty': Marvell's Cromwell in 1654.” In The Golden and the Brazen World: Papers in Literature and History, 1650-1800, edited by John M. Wallace, 17-53. Berkeley: University of California Press, 1985.

Holberton, Edward. Poetry and the Cromwellian Protectorate: Culture, Politics, and Institutions. Oxford: Oxford University Press, 2008. 
Holinshed, Raphael. The first and second volumes of Chronicles, rev. edn. London: John Hooker, alias Vowell, 1587.

Horwood, Alfred J., ed. A Common-place book of John Milton: and a Latin essay and Latin verses presumed to be by Milton, Camden Society Publications, n.s. 16. London: Camden Society, 1878.

Jones, Henry. A Remonstrance of Divers Remarkeable Passages concerning the Church and Kingdome of Ireland. London: for Godfrey Emerson and William Bladen, 1642.

Kerrigan, John. Archipelagic English: Literature, History, and Politics 1603-1707. Oxford: Oxford University Press, 2008.

King, John N. “Was Spenser a Puritan?” Spenser Studies 6 (1985): 1-31.

King, John N. "Spenser's Religion.” In The Cambridge Companion to Spenser, edited by Andrew Hadfield. 200-216. Cambridge, Cambridge University Press, 2001.

Komorowski, Michael. "Public Verse and Property: Marvell's 'Horatian Ode' and the Ownership of Politics". ELH 79 (2012): 315-40.

MacDonald, Alan R. The Jacobean Kirk, 1567-1625: Sovereignty, Polity, and Liturgy. Aldershot: Ashgate, 1998.

Maley, Willy. "How Milton and some contemporaries read Spenser's View." In Representing Ireland: Literature and the origins of conflict, 1534-1660, edited by Brendan Bradshaw, Andrew Hadfield, and Willy Maley. 191-208. Cambridge: Cambridge University Press, 1993.

Maley, Willy. Salvaging Spenser: Colonialism, Culture and Identity. Houndmills: Palgrave Macmillan, 1997.

Maley, Willy, and Adam Swann. "Is this the Region ... That we must change for Heav'n?': Milton on the Margins." In Region, Religion and English Renaissance Literature, edited by David Coleman. 139-152. Aldershot: Ashgate, 2013.

Maltzahn, Nicholas von. An Andrew Marvell Chronology. Basingstoke: Palgrave Macmillan, 2005.

Marvell, Andrew. Miscellaneous Poems. London: Robert Boulter, 1681.

Mazzeo, Joseph A. “Cromwell as Machiavellian Prince in Marvell's 'An Horatian Ode'." Journal of the History of Ideas 21 (1960): 1-17.

McCabe, Richard A. "The Masks of Duessa: Spenser, Mary Queen of Scots, and James VI." ELR 17 (1987): 224-242.

This is an Accepted Manuscript of an article published by Taylor \& Francis in Seventeenth 
McCabe, Richard A. Spenser's Monstrous Regiment: Elizabethan Ireland and the Poetics of Difference. Oxford: Oxford University Press, 2002.

Milton, John. Articles of Peace, Made and Concluded with the Irish Rebels, and Papists [...] and A Representation of the Scotch Presbytery at Belfast in Ireland. Upon all which are added Observations. In The Complete Works of John Milton, Volume VI: Vernacular Regicide and Republican Writings, edited by N. H. Keeble and Nicholas McDowell. 187-249. Oxford: Oxford University Press, 2013.

Mottram, Stewart. “'With guiltles blood oft stained': Spenser's Ruines of Time and the saints of St Albans.” Spenser Studies 31/32 (2016/2017): 533-56.

Nedham, Marchamont. Mercurius Politicus 1650. Facsimile reprint with notes by Peter Thomas. The English Revolution III: Newsbooks 5, Volume 1. London: Cornmarket Press, 1971.

Nedham, Marchamont. The case of the common-wealth of England, stated. London: E. Blackmore and R. Lowndes, 1650.

Norbrook, David. "Marvell's Horatian Ode and the Politics of Genre". In Literature and the English Civil War, edited by Thomas Healy and Jonathan Sawday, 14769. Cambridge, Cambridge University Press, 1990.

Norbrook, David. Writing the English Republic: Poetry, Rhetoric, and Politics, 16271660. Cambridge: Cambridge University Press, 1998.

Patterson, Annabel. “Lady State's First Two Sittings: Marvell's Satiric Canon”. Studies in English Literature 40.3 (2000): 395-411.

Raymond, Joad. "Complications of Interest: Milton, Scotland, Ireland, and National Identity in 1649". Review of English Studies 55 (2004): 315-45.

Smith, Nigel, ed. The Poems of Andrew Marvell, rev. ed. London and New York: Routledge, 2013.

Spenser, Edmund. A View of the State of Ireland: from the first printed edition (1633), edited by Andrew Hadfield and Willy Maley. Oxford: Blackwell, 1997.

Spenser, Edmund. A View of the State of Ireland, Written dialogue-wise betweene Eudoxus and Irenaeus. In The Historie of Ireland, collected by three learned authors, edited by James Ware. Dublin: Society of Stationers, 1633. Huntington Library, California: Rare Books 28118.

Stevenson, David. "Graham, James, first marquess of Montrose (1612-1650)". In Oxford Dictionary of National Biography, edited by H. C. G. Matthew and 
Brian Harrison, 60 vols. XXIII: 189-195. Oxford: Oxford University Press, 2004.

Temple, John. The Irish Rebellion [...] Together With the Barbarous Cruelties and Bloody Massacres which ensued thereupon. London: R. White for Samuel Gellibrand, 1646.

Wallace, John. Destiny his Choice: The Loyalism of Andrew Marvell. Cambridge: Cambridge University Press, 1968.

Ware, James, ed. The Historie of Ireland, collected by three learned avthors. Dublin: Society of Stationers, 1633. Huntington Library, California: Rare Books 28118. Wilding, Michael. Dragons Teeth: Literature in the English Revolution. Oxford: Clarendon, 1987.

Wilson, John. Fairfax: A life of Thomas, lord Fairfax. London: John Murray, 1985.

Worden, Blair. "The Politics of Marvell's Horatian Ode." Historical Journal 27.3 (1984): 525-547.

Worden, Blair. Literature and Politics in Cromwellian England: John Milton, Andrew Marvell, Marchamont Nedham. Oxford and New York: Oxford University Press, 2007.

\section{NOTES}

1 “An Horatian Ode", in Smith, ed., Poems of Marvell, 267-79 (1. 58); hereafter cited as 'Marvell, "Ode"”. As an occasional poem marking 'Cromwell's return from Ireland', and anticipating his military successes in Scotland, there is broad critical agreement that the "Ode" was composed between Cromwell's return to London on 1 June, and his crossing into Scotland at the head of the parliamentary army on 22 July 1650. See Smith, ed., Poems of Marvell, 267.

2 Marvell, “Ode”, 11. 57 and 61. 'The contrast between Charles's own conduct and that of his killers' at this mid-point in the poem is particularly emphasized by Worden, Literature and Politics, 86.

${ }^{3}$ Criticism of Marvell's "Ode" was divided in the second half of the twentieth century between those, like Coolidge ("Marvell and Horace") and Everett ("Shooting of the Bears"), who admire Marvell's 'Horatian' balance between the competing claims of Cromwell and Charles I, and those, like Mazzeo (“Cromwell as Machiavellian Prince"), Wallace ("Destiny his Choice"), Worden ("Politics of Horatian Ode" and its fuller development in Literature and Politics, chapter 5), and Norbrook ("Politics of Genre"), who argue that the poem sides with Cromwell, signalling a switch in Marvell's political allegiance from the royalism of the pre-1650 poems to the pragmatic 'loyalism' of his republican phase.

${ }^{4}$ Marvell, "Ode”, 11. 85-6.

This is an Accepted Manuscript of an article published by Taylor \& Francis in Seventeenth Century on 17 Sep 2018, available online:

http://www.tandfonline.com/10.1080/0268117X.2018.1484636. 


\begin{abstract}
5 Marvell, “Ode”, 1. 114.
${ }^{6}$ Marvell, Miscellaneous Poems, 116; cf. Marvell, “Ode”, 11. 35-6. Nigel Smith, like other of the poem's modern editors, accepts the manuscript reading. The additions to Bodleian Library, Oxford, MS Eng. Poet. d. 49 - a copy of the printed 1681 Miscellaneous Poems containing MS corrections and interleaved transcriptions of the cancelled Cromwell poems - have been persuasively (although inconclusively) attributed to Marvell's nephew, Will Popple. See Patterson, “Lady State’s Two Sittings”, 396-402. The change from 'Kingdome' to 'kingdoms' is one of several variations in the Bodleian manuscript from the printed text of "An Horatian Ode" in the two known un-cancelled copies (British Library C.59.i.8 and Huntington Library 79660). See von Maltzahn, An Andrew Marvell Chronology, 224-25.
\end{abstract}

${ }^{7}$ See Baker, Between Nations, 124-68; and Kerrigan, Archipelagic English, 233-34 passim. For a recent review of the aims and achievements, as well as limitations, of archipelagic criticism, see Baker, "Britain Redux".

${ }^{8}$ Baker, Between Nations, 135; Coleman, ed., Region, Religion, 8.

${ }^{9}$ For the Levellers, see Wilding, Dragons Teeth, chapter 5, and Norbrook, "Politics of Genre", 156-7. For Fairfax's objections, see Wilson, Fairfax, 159-60, and Fairfax's later account of his resignation, in Short Memorials, 126-7.

${ }^{10}$ Worden, "Politics of Horatian Ode", and Literature and Politics, chapter 5; Norbrook, "Politics of Genre".

${ }^{11}$ Worden, "Politics of Horatian Ode", 536.

${ }^{12}$ Marvell, “Ode", 1. 106.

${ }^{13}$ Dzelzainis, ed., Rehearsal Transpros'd, 62.

14 Ibid.

${ }^{15}$ Milton, Articles of Peace: Observations, 247, 242, 228, 247; hereafter cited as Observations. For the text of A Necessary Representation (dated 15 February 1649/50), see ibid., 228-31. For Milton's response, ibid., 239-49.

${ }^{16}$ Observations, 232.

${ }^{17}$ Mercurius Politicus, 1-2. Ibid., 59, 56.

${ }^{18}$ Horwood, Common-place book of Milton; Maley, "How Milton read Spenser".

${ }^{19}$ Spenser, View, ed. Hadfield and Maley, 101. Hereafter cited as 'Spenser, View'.

${ }^{20}$ Ibid., 11, 153.

${ }^{21}$ Cited in Maley, Salvaging Spenser, 121, 123.

${ }^{22}$ Spenser, View, 89 and 159; cf. Spenser, View of Ireland, in Huntington 28118, 63 and 118. View of Ireland is paginated separately from other works in Huntington 28118.

${ }^{23}$ Spenser, View, 89

${ }^{24}$ Spenser, View, 159.

${ }^{25}$ Ibid., 160.

${ }^{26}$ Maley, 'How Milton read Spenser', 202, 195. Norbrook, "Politics of Genre”, 152.

${ }^{27}$ Milton, Observations, 232. The claim to 'Autority' comes on the title page to Observations, reproduced in ibid., 188. Daems, "Dividing Conjunctions", 52. See also Corns, "Milton's Observations", both cited in Maley and Swann, "Milton on the Margins", 140.

This is an Accepted Manuscript of an article published by Taylor \& Francis in Seventeenth

Century on 17 Sep 2018, available online:

http://www.tandfonline.com/10.1080/0268117X.2018.1484636. 
${ }^{28}$ Milton, Observations, 224.

${ }^{29}$ Ibid., 238.

${ }^{30}$ Ibid., 237.

${ }^{31}$ Marvell, “Ode”, 11. 83-4.

32 Ibid., 11. 74, 77-82.

${ }^{33}$ Ibid., 11. 33, 74. Mercurius Politicus, 17-32.

${ }^{34}$ Mercurius Politicus, 29. Worden, "Politics of Horatian Ode", 536.

${ }^{35}$ Mercurius Politicus, 21.

${ }^{36}$ Mercurius Politicus, 22, 53.

${ }^{37}$ Komorowski, "Public Verse and Property", 323-4.

${ }^{38}$ Mercurius Politicus, 43, 23.

${ }^{39}$ Spenser, View, 96.

${ }^{40}$ Coughlan, "Cheap and Common Animals", 207.

${ }^{41}$ McCabe, Spenser's Monstrous Regiment, 148. Spenser, View, 59.

42 Ibid., 45.

${ }^{43}$ Ibid., 63; Maley, Salvaging Spenser, 138-42; McCabe, Monstrous Regiment, 142-64.

${ }^{44}$ Spenser, View, 110-11. See Grant, "George Gordon”; MacDonald, The Jacobean Kirk, 57-60.

${ }^{45}$ Spenser, View, 85.

46 Ibid., 54.

${ }^{47}$ Ibid., 84, 153.

${ }^{48}$ Ibid., 154.

${ }^{49}$ Ibid., 155.

${ }^{50}$ Coughlan, "“Cheap and Common Animals", 208.

${ }^{51}$ Canny, Making Ireland British, 463.

${ }^{52}$ A Remonstrance, B1r-v.

${ }^{53}$ Mercurius Politicus, 23.

${ }^{54}$ Spenser, View, 11.

55 Ibid., 153.

${ }^{56}$ Milton, Observations, 236.

${ }^{57}$ Ibid., 236.

${ }^{58}$ Spenser, View, 155. King, “Was Spenser a Puritan?”; King, “Spenser's Religion”. See also Mottram, "With guiltles blood"”.

${ }^{59}$ Spenser, View, 93.

${ }^{60}$ Ibid., 155.

${ }^{61}$ Milton, Observations, 246, 232, 242.

62 Ibid., 248, 241.

${ }^{63}$ Ibid., 244, 245.

${ }^{64}$ Ibid., 232.

${ }^{65}$ Raymond, "Complications of Interest”, 334, cited in Maley and Swann, "Milton on the margins", 141. Ibid., 142.

This is an Accepted Manuscript of an article published by Taylor \& Francis in Seventeenth 
${ }^{66}$ Spenser, View, 110. Milton, Observations, 248. For Milton's probable borrowing from Spenser, see ibid., 622, n. 171.

${ }^{67}$ Holinshed, Chronicles, 6.

${ }^{68}$ Ibid., 5. For more on the 'Scithian' origins of Scots and Picts, see McCabe, Spenser's Monstrous Regiment, 143.

${ }^{69}$ Here I am thinking not only of Spenser's View, but of Spenser's identification of Mary Queen of Scots with the catholic queen Duessa in Faerie Queene V - an identification that caused 'great offence' to Mary's son, James VI of Scotland, as the diplomatic correspondence reveals. See McCabe, "Masks of Duessa"; Hadfield, Matter of Britain, 122-36; Maley, Salvaging Spenser. For the correspondence, see Bowes to Burghley, 1 November 1596 and 12 November 1596, calendared in Guiseppi, ed., CSP: Scotland, XII: nos. 288 and 291.

${ }^{70}$ For the impact of Politicus, see Worden, Literature and Politics, 21-23.

${ }^{71}$ Mercurius Politicus, 17, 59.

${ }^{72}$ Ibid., 21, 23, 59.

${ }^{73}$ Ibid., 36, 124.

${ }^{74}$ Ibid., 124.

${ }^{75}$ A Vindication, D3r; for discussion, see Gribben, "Cromwellian Invasion”, 9.

${ }^{76}$ Marvell, “Ode”, 11. 105-112.

77 "Plaid, n.1 (2a)", in OED Online. Oxford: Oxford University Press, 2017.

http://www.oed.com/view/Entry/144969?rskey=5ZqKMN\&result=1\&isAdvanced=false (accessed 30 October 2017).

${ }^{78}$ Spenser, View, 63.

${ }^{79}$ See the discussion in Smith, ed., Poems of Andrew Marvell, 278 (note to line 106).

${ }^{80}$ Kerrigan, Archipelagic English, 233.

${ }^{81}$ Stevenson, "Graham, James".

${ }^{82}$ Mercurius Politicus, 19.

${ }^{83}$ Ibid., 40.

${ }^{84}$ Stevenson, "Graham, James".

${ }^{85}$ Kerrigan, Archipelagic English, 233.

${ }^{86}$ Worden, "Politics of Horatian Ode"; Norbrook, "Politics of Genre".

${ }^{87}$ Mercurius Politicus, 59.

${ }^{88}$ Marvell, “Ode”, 1. 9.

${ }^{89}$ Worden, "Politics of Horatian Ode"; Norbrook, "Politics of Genre". Marvell, "Ode", 11. 33, 38.

${ }^{90}$ Ibid., 11. 12, 35.

${ }^{91}$ Ibid., 11. 101-4.

${ }^{92}$ Ibid., 11., 99-100, 105.

${ }^{93}$ Nedham, Case of the common-wealth, B3r, cited in Worden, "Politics of Horatian Ode", 535.

${ }^{94}$ Marvell, “Ode”, 1. 66.

95 In Smith, ed., Poems of Marvell, $281-98$ (11. 126, 128-30); hereafter cited as 'Marvell, "First Anniversary",.

This is an Accepted Manuscript of an article published by Taylor \& Francis in Seventeenth Century on 17 Sep 2018, available online:

http://www.tandfonline.com/10.1080/0268117X.2018.1484636. 


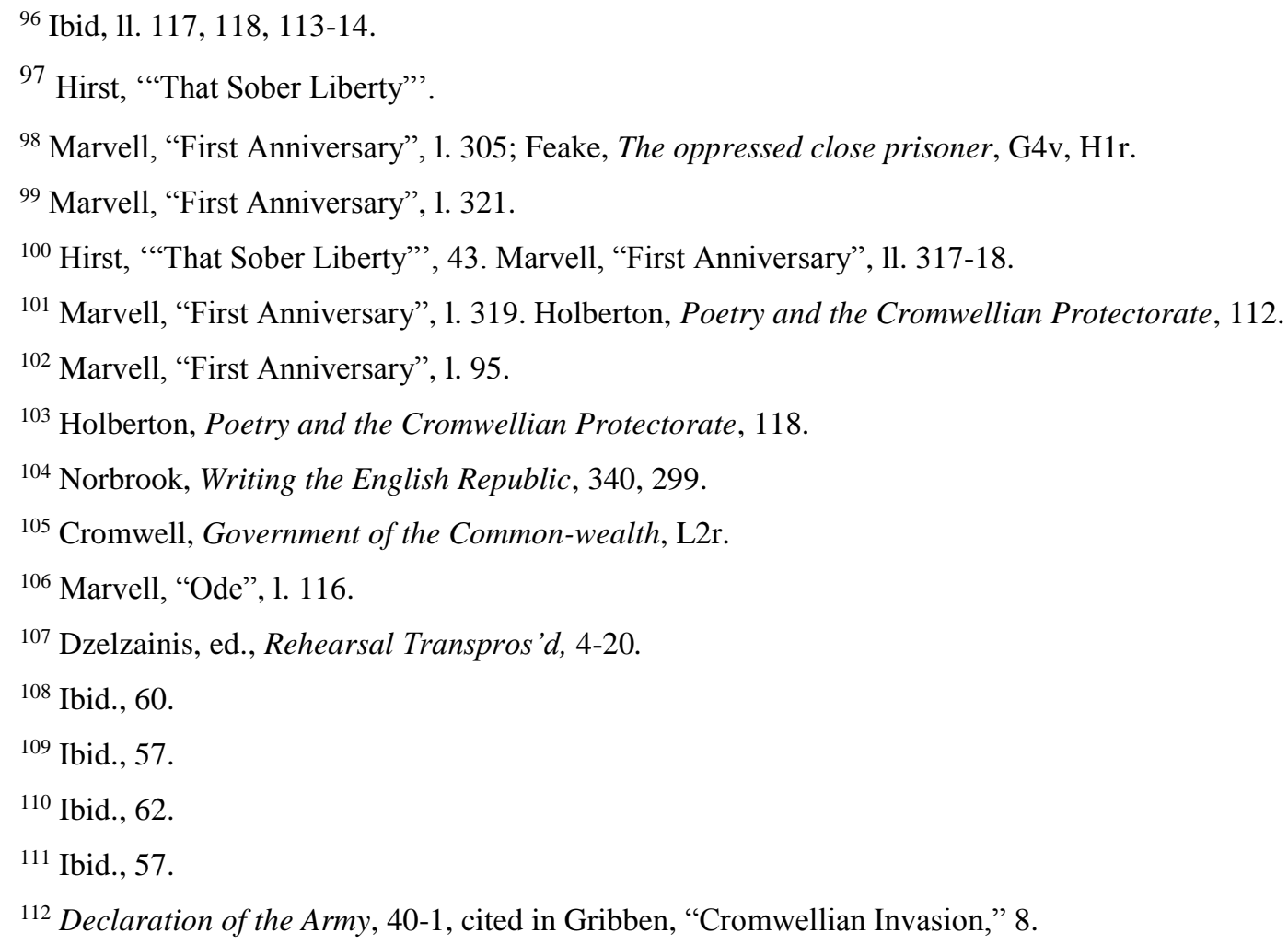

